Пороховата Слизавета Олександрівна студентка кафедри публічного права факультету соціології і права Національного технічного університету України «Київський політехнічний інститут імені Ігоря Сікорського», вул. Бульвар Кольцова, 14-д, м. Київ, 03094, тел.: (063) 873-76-15, e-mail: porokh409@ukr.net, https://orcid.org/0000-0001-8744-4031.

Островська Альона Сергї̈вна студентка кафедри публічного права факультету соціології і права Національного технічного університету України «Київський політехнічний інститут імені Ігоря Сікорського», вул. Всіхсвятська, 16, м. Чернігів, 14030, тел.: (093) 957-22-62, e-mail: alyonaostrovska2002@gmail.com, https://orcid.org/0000-0003-3951-4407.

\title{
ПРАВОВІ АСПЕКТИ ЛЕГАЛІЗАЦІЇ ОДНОСТАТЕВИХ ШЛЮБІВ В УКРАЇНI
}

Анотація. У даній статті розглянуто доцільність легалізації одностатевих шлюбів, оскільки сьогодні країні, яка прагне називати себе демократичною та правовою, замало мати лише розвинуту законодавчу базу та проголосити додержання принципу верховенства права, бо наразі практика доводить, що повністю демократична держава повинна поважати та захищати права всіх ii членів суспільства. На жаль, в Україні досі залишаються категорії населення, які зазнають певних утисків у своїх правах. В даній статті буде розглянуто питання щодо обмежень одностатевих пар, які вони зазнають в сфері сімейного права. Тому, особливу увагу в даному питанні було присвячено дослідженню положень Конституції України, Сімейного кодексу України, а також міжнародних договорів про шлюб та сімю, що ратифікувала Україна. Більше того, для того аби в подальшому в даному питанні не виникало певних колізій та прогалин в статті було розроблено рекомендації щодо внесення відповідних змін до національного законодавства з метою реформування інституту шлюбу в Україні. Також особливу увагу було приділено визначенню форми та обсягу майбутнього законодавства про реєстроване цивільне партнерство.

Багато країн в світі вже визнали одностатеві шлюби та надали їх учасникам всі ті законні права та обов'язки, які породжує шлюб для його сторін. Зокрема, серед багатьох європейських країн на досвід та практику, яких Україна зважає в багатьох інших сферах своєї діяльності, як економіка, політика та інше, вже, 
також, повністю визнали одностатеві шлюби. До ряду таких країн належать, зокрема Німеччина, Франція, Фінляндія та ін. Тому в даній статті для детальнішого та всебічного дослідження було використано практику країн-членів Свропейського Союзу, в яких санкціоновано державну реєстрацію одностатевих шлюбів, щодо їх узаконення, забезпечення правової охорони та чіткого окреслення законних прав, свобод та інтересів учасників.

Ключові слова: дискримінація, шлюб, одностатеві шлюби, реєстроване цивільне партнерство.

Porokhovata Yelyzaveta Oleksandrivna Student of the Department of Public Law, Faculty of Sociology and Law, National Technical University of Ukraine "Kyiv Polytechnic Institute named after Igor Sikorsky”, Koltsova Boulevard St., 14-d, Kyiv, 03094, tel.: (063) 873-76-15, e-mail: porokh409@ukr.net, https://orcid.org/0000-00018744-4031

Ostrovska Alyona Serhiivna Student of the Department of Public Law, Faculty of Sociology and Law, National Technical University of Ukraine "Kyiv Polytechnic Institute named after Igor Sikorsky”, Vsihsvyatska St., 16, Chernihiv, 14030, tel.: (093) 957-22-62, e-mail: alyonaostrovska2002@gmail.com, https://orcid.org/0000-00033951-4407.

\section{LEGAL ASPECTS OF LEGALIZATION OF SEXUAL MARRIAGES IN UKRAINE}

Abstract. This article discusses the expediency of legalizing same-sex marriage, because today a country that seeks to call itself democratic and legal, it is not enough to have a developed legal framework and declare the rule of law, because now practice shows that a fully democratic state must respect and protect the rights of all members of society. Unfortunately, there are still categories of the population in Ukraine who are subject to certain oppression of their rights. This article will look at the limitations of same-sex couples on family law. Therefore, special attention in this issue was paid to the study of the provisions of the Constitution of Ukraine, the Family Code of Ukraine, as well as international agreements on marriage and family, ratified by Ukraine. Moreover, in order to avoid further conflicts and gaps in this issue, the article developed recommendations for appropriate amendments to national legislation in order to reform the institution of marriage in Ukraine. Special attention was also paid to determining the form and scope of future legislation on registered civil partnership.

Many countries around the world have already recognized same-sex marriage and granted all the legal rights and obligations of marriage to its parties. In particular, 
among many European countries, the experience and practice that Ukraine considers in many other areas of its activities, such as economics, politics, etc., have already been fully recognized as same-sex marriages. Such countries include, in particular, Germany, France, Finland and others. Therefore, in this article for a more detailed and comprehensive study used the practice of EU member states, which authorized the state registration of same-sex marriages, on their legalization, legal protection and clear delineation of legal rights, freedoms and interests of participants.

Keywords: discrimination, marriage, same-sex marriages, registered civil partnership.

Постановка проблеми. Забезпечення прав і свобод людини є пріоритетним напрямом діяльності будь-якої демократично-правової держави, зокрема, особлива увага в контексті цього приділяється недопущенню виникнення передумов для поширення дискримінації в будь-якій сфері суспільного життя. Однак, не всі держави відповідно до стану свого економічного та культурного розвитку встигають за динамікою суспільних відносин, тому їх законодавство, на жаль, не відповідає потребам сучасного суспільства. Наочно це можна простежити, досліджуючи питання легітимізації одностатевих шлюбів, які ще не у всіх країнах світу є узаконеними. Україна не стала винятком серед тих держав, які ще не закріпили на законодавчому рівні можливість юридичного оформлення одностатевих шлюбів.

Кожного дня в суспільстві відбуваються певні зміни та трансформації, які пов'язані з появою нових ідеалів, духовних та гуманістичних цінностей, зміною культурних традицій та моральних норм [1, с. 166]. Нові погляди на сім'ю та шлюб не так добре зуміли закріпитися в Україні, ніж в західноєвропейських країнах. Невідповідність чинного сімейного законодавства України сучасним змінам у суспільстві зумовлює актуальність даної теми.

Причиною для обговорення проблеми легітимізації одностатевих шлюбів також є негативні наслідки, які вона породжує для представників ЛГБТ-спільнот, одним з яких є дискримінаційні положення сімейного законодавства держави. В Україні наразі є багато (становлять майже 30-40 відсотків від всього населення у 2017 році, що утричі більше у порівнянні 3 попередніми роками [2, с. 96]) одностатевих пар як чоловічих, так і жіночих, які переважно не живуть відкрито як сім’і і не мають жодних прав та обов`язків, що передбачає шлюб: вони не можуть залишати своє майно у спадок або успадковувати майно свого партнера чи партнерки, не мають права на аліменти, не можуть відвідувати один одного в медичних закладах, разом виховувати дітей тощо. Таким чином, створюється ситуація, за якої певна група людей залишається поза правом як за змістом регулювання їх відносин між собою, так і за суттю користування певними 
правами, які гарантовані для всіх людей.

Аналіз останніх досліджень і публікацій. Тенденції та проблеми легітимізації одностатевих шлюбів в Україні досліджено в науковій праці Миронця О. М., питання щодо дискримінації прав сексуальних меншин у відповідності до чинного національного законодавства розглядали Ярманова Г., Маєрчик М., Покальчук О., Шимко С., Марценюк Т., Гриник О. Окрім цього, було використано праці науковців Булеца С. Б., Ревуцька I. Е. та Бірюков А. I.

Мета статті - дослідження сучасного стану сімейного законодавства України щодо питання закріплення законності одностатевих шлюбів та юридичних наслідків для подружжя, а також розробка стратегії оптимізації сучасного правового становища одностатевих сімей в Україні, зважаючи на досвід країн-членів Свропейського Союзу.

Виклад основного матеріалу. Поняття «шлюб» можна трактувати порізному, оскільки універсального та офіційного його визначення не існує. Так, Бірюков I. А. визначає поняття шлюбу як духовно-правовий стан життя жінки та чоловіка, започаткований державною реєстрацією їх погодженого, добровільного, належним чином оформленого волевиявлення про створення сім'ї і прийняття на себе передбачених законом прав і обов'язків подружжя [1, с. 138]. Червоний Ю. С. вважав, що шлюб - це юридичний факт, з яким пов'язують виникнення сім'ї, прав та обов'язків подружжя [1, с. 136].

Аналізуючи думки вчених щодо визначення поняття шлюбу, можна стверджувати, що в основному воно грунтується на тлумаченні ч. 1 ст. 51 Конституції України, а також ч. 6 ст. 7 Сімейного кодексу, де шлюб описано як сімейний союз між чоловіком та жінкою $[3,4]$.

Досить суперечливим залишається той факт, що одностатеві стосунки відповідно до даних трактувань не можуть бути узаконені у формі державної реєстрації, тим самим створюючи умови виникнення дискримінації щодо представників ЛГБТ-спільнот, оскільки факт шлюбу передбачає для подружжя наявність низки майнових та немайнових прав: право на материнство, батьківство, право на спадок, на вдочеріння або всиновлення дитини дружини або чоловіка, право на застосування допоміжних репродуктивних технологій, право на поділ спільного сумісного майна, набутого під час шлюбу, право на утримання після розірвання шлюбу та багато інших прав [5, с. 29]. Більше того, чинне законодавство України, а саме ч. 3 ст. 211 Сімейного кодексу України, не передбачає можливостей, за яких одностатеві сімейні пари можуть бути усиновлювачами.

Майнові права одностатевих сімейних пар як подружжя також обмежені. Якщо дружина та чоловік мають рівні права на володіння, користування i розпоряджання майном, що належить їм на праві спільної сумісної власності, то 
одностатева сім'я може реалізувати право спільної сумісної власності на майно, набуте під час проживання однією сім'ю, шляхом укладення договорів при здійсненні кожної значної купівлі [5, с. 30].

За подібною логікою одностатеві сімейні пари не можуть отримати, наприклад, банківський кредит для «молодих сімей» чи сімейну іпотеку на житло, «сімейні» знижки у спортивних клубах та в інших рекреаційних закладах, у них, також, немає можливості отримувати пенсію партнерки чи партнера посмертно.

Низка міжнародних договорів, які ратифікувала Україна стоять на захисті прав, свобод та законних інтересів людини, зокрема Загальна декларація прав людини, Свропейська Конвенція про захист прав та основних свобод, два Міжнародних пакти про права людини відображають занепокоєння спільноти щодо поширення у світі расової та статевої дискримінації, тим самим гарантуючи унеможливлення зменшення чи звуження, визнаних світовою спільнотою, обсягу та змісту прав і свобод людини, незважаючи на іiі орієнтацію, життєві цінності, погляди на життя чи інтереси. Якщо мова зайшла за міжнародні договори $з$ прав людини, то взагалі ратифікована Верховної Радою України, Конвенція ООН про укладання та визнання дійсності шлюбів серед пунктів, за якими шлюби визнаються не дійсними не передбачає жодного того, який би свідчив, що особи однієї статі не можуть узаконити свої стосунки. Однак, ратифікована Україною Свропейська конвенція про всиновлення дітей була прийнята нею за умовою iз застереженням: подальшим невизнання права на адопцію одностатевих партн ерств. I обгрунтуванням такої позиції з боку України було невідповідність «національним традиціям», моральним та культурним цінностям існування даного типу сім\&apos;ї. Однак суспільство розвивається, міняється, а 3 ним і змінюється його ментальність, за якою люди намагаються ставати більш толерантними один до одного.

У світі існують країни, де дозволені одностатеві шлюби, і не рідко українці звертаються до урядів таких країн аби зареєструвати шлюбні відносини зі своїм партнером чи партнеркою. На сьогоднішній день одностатеві шлюби $\epsilon$ дозволеними і офіційно реєструються в багатьох країнах-членах СС, серед яких - Австрія, Греція, Данія, Естонія, Італія, Кіпр, Німеччина, Угорщина, Хорватія, Чехія тощо. Найкращим варіантом врегулювання даного питання для цих країн було запровадження цивільного (реєстрованого) партнерства - відносно нового правового інституту, який регулює стосунки людей у сімейному парному союзі, незалежно від їхньої статі. Якщо розтлумачувати зміст назви, то «реєстровим» воно називається тому, що підлягає офіційній реєстрації у формі документу, «цивільним», оскільки покликане регулювати приватні відносини між людьми, а «партнерство», бо регулює партнерські відносини. Даний вид «шлюбу» $\epsilon$ можливим не тільки для одностатевих пар, оскільки в європейських країнах його 
використовують й ті особи, які 3 певних причин просто не бажають укладати шлюб. Порівняно зі шлюбом реєстроване партнерство може містити обмеження стосовно права обирати спільне ім'я, права усиновлювати дитину або звертатися до допоміжних репродуктивних технологій, презумпції батьківства. Можуть також встановлюватись обмеження стосовно можливості цивільного партнерства залежно від місця постійного проживання або громадянства партнерів [7, с. 485].

Сімейним та цивільним законодавством встановлюються тільки деякі аспекти цивільного партнерства. Відповідно до сімейного законодавства Данії, до цивільного (реєстрованого) партнерства застосовуються положення про встановлення шлюбного віку, заборону укладення шлюбу, процедуру реєстрації шлюбу одностатевої пари, а 31 лютого 2017 року - визнання офіційним той шлюб, що був укладений за межами країни [8].

Питанню регулювання цивільного партнерства у Франції присвячено окремі положення Пакту цивільної солідарності [9]. Даний нормативно-правовий акт покликаний регулювати саме майнові відносини партнерів. Він вирішує питання щодо матеріальної допомоги (ст. 515-4), особистого майна кожного з партнерів (ст. 515-5) та спільності майна (ст. 515-5-1).

Національному законодавству Угорщини відомі два види формалізованих сімейних відносин шлюбного характеру - шлюб та зареєстроване партнерство. До національного законодавства Угорщини поняття реєстрованого партнерства було запроваджено законом, який набрав чинності в липні 2009 року (Закон Угорщини про реєстроване партнерство). Відповідно до законодавства Угорщини, якщо шлюб - це виключно союз чоловіка та жінки, то зареєстроване партнерство, навпаки, укладається між одностатевими партнерами [7, с. 487].

Висновки. Шлюб не потрібно розглядати тільки як союз виключно між чоловіком та жінкою, оскільки він також може бути між особами однієї статті.

Досліджуючи Сімейний кодекс України, можна виявити низку суперечливих положень, які з одного боку не заперечують законне існування одностатевого шлюбу, але водночас передбачають певні заборони щодо його реєстрації, тим самим обмежуючи права та свободи представників ЛГБТспільнот. Для того аби забезпечити певний баланс в суспільстві та наблизитися до стандартів європейського законодавства, законодавцю треба розробити план заходів щодо форми узаконення одностатевих шлюбів.

Цивільне (реєстроване) партнерство — це компроміс між неприйняттям суспільством одностатевих шлюбів та необхідністю становлення права на шлюб осіб, що виявляють бажання його реєстрації, оскільки воно $є$ фактично еквівалентне шлюбу. Юридичні наслідки цивільного партнерства ідентичні шлюбним відносинам, так як аспекти цивільного партнерства встановлюються не тільки спеціальним законом, але й сімейним та цивільним законодавством. 
Для регулювання відносин щодо реєстрації цивільного партнерства в нашій країні варто:

- внести зміни до Конституції України, зокрема додати статтю 51-1, яка б легалізувала цивільне партнерство для одностатевих пар;

- видати акт спеціального законодавства про цивільне (рестроване) партнерство (наприклад, Закон України “Про реєстроване партнерство”);

• внести необхідні корективи до Сімейного кодексу, Цивільного кодексу та Цивільно процесуального кодексу України.

\section{Jimepamypa:}

1. Бірюков А. І. До законодавчого визначення поняття шлюбу. Проблеми цивільного та підприємницького права в Україні. 2017. №10. С. 136-139;

2. Кравчук А., Грибанов А. Право на пошуки щастя. Наш світ. 2017. 96 с.;

3. Конституція України, прийнята Верховною Радою України 28 червня 1996 року. URL: https://zakon.rada.gov.ua/laws/show/254\%D0\%BA/96-\%D0\%B2\%D1\%80\#Text ;

4. Сімейний кодекс України від 10 січня 2002 року № 2947-III. URL: https://zakon.rada.gov.ua/laws/show/2947-14\#Text;

5. Ярманова Г., Маєрчик М., Покальчук О., Шимко С., Марценюк Т., Гриник О. ЛГБТсім'ї в Україні: соціальні практики та законодавче регулювання : збірка / ред. Г. Ярманова. Київ : Інсайт, 2012. 77 с.;

6. Європейська конвенція про усиновлення дітей (переглянута), ратифіковано Законом № 3017-VI (3017-17) від 15.02.2011. URL: https://zakon.rada.gov.ua/laws/show/994_a17\#Text;

7. Булеца С. Б., Ревуцька I. Е. Інститут заресстрованого партнерства та фактичні шлюбні відносини в Україні i країнах-членах $\epsilon C$ : поняття й особливості. URL: http://baltijapublishing.lv/omp/index.php/bp/catalog/download/35/553/1161-1?inline=1 ;

8. Schanda B. A jog lehetõségei a család védelmére. URL: http://ias.jak.ppke.hu/hir/ias/20122sz/09.pdf ;

9. Code civil des Français (Version consolidée au 27 juillet 2017). URL: https://www.legifrance.gouv.fr/affichCode.do?idArticle=LEGIARTI000027431993\&idSectionTA=LE GISCTA000006136117\&cidTexte=LEGITEXT000006070721\&dateTexte $=20170727$.

\section{References:}

1. Birukov A. I. (2017) Do zaconodavchogo vyznachenia poniatia shlyubu. Problemy cyvylnogo ta pidpryemnickogo prava v Ukraini[ To the legislative definition of marriage. Problems of civil and business law in Ukraine ]. №10, 136-139 [in Ukrainian]

2. Kravchyk A., Grybanov A. (2017) Pravo na poshuky schastia [The right to seek happiness]. Nash svit - Our world, 96 [in Ukrainian]

3. Konstytucia Ukrainy, pryniata Verhovnou Radou Ukrainy 28 chervnia 1996 roku [Constitution of Ukraine, adopted by the Verkhovna Rada of Ukraine on June 28, 1996]. (n.d.). zakon.rada.gov.ua. Retrieved from https://zakon.rada.gov.ua/laws/show/254\%D0\%BA/96\%D0\%B2\%D1\%80\#Text [in Ukrainian]

4. Simeyniy kodecs Ukrainy vid 10 sichnia 2002 roku, № 2947-III [ Family Code of Ukraine from January 10, 2002, № 2947-III]. (n.d.). zakon.rada.gov.ua. Retrieved from https://zakon.rada.gov.ua/laws/show/2947-14\#Text [in Ukrainian] 
5. Iarmanova G., Mayerchik M., Pokalchuk O., Shymko S., Marchenuk T., Grynyk O. (2012) LGBT-simiy v Ukraini: sicialny praktyky ta zaconodavchie reguliuvania [ LGBT families in Ukraine: social practices and legislation]. : zbyrka / redakcia G. Iarmanova [ Insayt] - collection edited by Yarmanov [ Insight ], Kyiv, 77 [in Ukrainian]

6. Europeyska convencia pro usynovlenia ditey (pereglianuta) ratyfikovana Zakonom № 3017VI (3017-17) vid 15.02.2011 [ European Convention on Adoption of Children (revised), ratified by Law № 3017-VI (3017-17) of 15.02.2011].(n.d.). zakon.rada.gov.ua. Retrieved from https://zakon.rada.gov.ua/laws/show/994_a17\#Text [in Ukrainian]

7. Buleca S. B., Revucka I. E. Instytut zareyestrovanogo partnerstva ta factychni shlubni vidnosyny v Ukraini i krainah-chlenah ES: ponatia y osoblyvosti [ The institution of registered partnership and actual marital relations in Ukraine and EU member states: concepts and features]. Retrieved from http://baltijapublishing.lv/omp/index.php/bp/catalog/download/35/553/11611 ? inline $=1$ [in Ukrainian]

8. Schanda B. A jog lehetõségei a család védelmére [And the rules of the family are very important]. Retrieved from http://ias.jak.ppke.hu/hir/ias/20122sz/09.pdf [in Hungarian] ;

9. Code civil des Français au 27 juillet 2017 [French Civil Code from of July 27, 2017]. Retrieved from https://www.legifrance.gouv.fr/affichCode.do?idArticle=LEGIARTI 000027431993\&idSectionTA=LEGISCTA000006136117\&cidTexte=LEGITEXT000006070721\&dat eTexte $=20170727$ [in French]. 